\title{
Evolution and nature of science instruction
}

\author{
A first-person account of changes in evolution instruction throughout a career \\ Lawrence C. Scharmann ${ }^{*}$
}

\begin{abstract}
In this article, I provide an analysis of my work (1985-present) with non-major biology students and science teacher candidates in developing strategies for teaching and enhancing learning with respect to evolutionary science. This first-person account describes changes in evolution instruction over the course of a career based on personal experiences, research-informed practices, and a critical collaboration with colleague Mike U. Smith. I assert four insights concerning the influence and efficacy of teaching nature of science (NOS) prior to the introduction of evolution within college courses for science non-majors and science teacher candidates. These insights are: (a) teach explicit NOS principles first; (b) integrate evolution as a theme throughout a course in introductory biology (but after NOS principles have been introduced); (c) use active learning pedagogies; and (d) use non-threatening alternative assessments to enhance student learning and acceptance of evolutionary science. Together, these insights establish a pedagogy that I (and my colleagues) have found to be efficacious for supporting novice students as they engage in the study of evolutionary science.
\end{abstract}

Keywords: Evolution, Nature of Science, Non-majors, Curriculum and Education

\section{Background}

My earliest attempts at teaching evolution were well intentioned. They were also naïve and quite inadequate. I taught accurate content but did not account for student resistance, administrative concerns, or questions from sometimes combative parents. I sought, as a then novice educator, advice from experienced biology teachers in my own school on how to more appropriately handle the instruction of evolutionary biology. The advice I received was equally well intentioned-'Just teach the concepts without ever mentioning evolution' or 'save evolution for the last unit in the academic year, then you can avoid all of the difficult questions parents sometimes ask.' However sincere their advice, it was also inadequate, intellectually dishonest, and did not appropriately characterize the power of scientific theories to explain, predict, and

*Correspondence: Ischarmann2@unl.edu

Department of Teaching, Learning, and Teacher Education, University of Nebraska, Lincoln, NE, USA serve as a lens by which to pose and answer scientific questions.

I ultimately revised my approach to teaching evolution by integrating critical nature of science (NOS) principles-e.g., recognize that science depends of necessity on degrees of uncertainty, the development of criteria, and the use of criteria by which to make decisions in the face of uncertainty-gained during my doctoral studies. I anxiously anticipated integrating my new insights into instruction for biology non-majors and science teacher candidates. It is these students, as a new university hire that I was assigned to teach. In the remainder of this article, I describe changes in my approach to teaching evolution based on personal experiences, research-informed practices, and a critical collaboration with colleague Mike U. Smith.

\section{The nature of science and naturalism}

Who better to say what is and is not science than scientists? There are established theories, standards, and methods as tools used in designing experiments, making

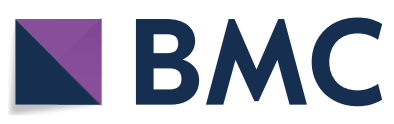

c) The Author(s) 2018. This article is distributed under the terms of the Creative Commons Attribution 4.0 International License (http://creativecommons.org/licenses/by/4.0/), which permits unrestricted use, distribution, and reproduction in any medium, provided you give appropriate credit to the original author(s) and the source, provide a link to the Creative Commons license, and indicate if changes were made. 
predictions, and interpreting results. Scientists trained to use these tools are in the best position to determine what counts as evidence in support or refutation of a given line of inquiry. Kuhn (2012), in his seminal Structure of Scientific Revolutions aptly described this as scientists deeply absorbed in scientific investigations through iterative use of a consensus theoretical framework or paradigm-in other words, scientists consummately engaged in normal science. While there is much practical validity in this point of view, scientists laying claim to be the ultimate arbiters of what is (or is not science) comes across to non-scientists, students, members of the general public etc., that science is elitist, authoritative, and condescending (Shamos 1995). This authoritative perception of science became a pervasive theme used by Phillip Johnson to disparage scientists as protective of theories, closed-minded to alternative explanations, and unwilling to consider anomalous evidence. Evolution, according to Johnson, was an atheist dogma due to an unbending allegiance to philosophical naturalism (Johnson 1993). Johnson painted a picture that was completely dualistic, a false dichotomy-he would have his readers choose either theism or atheism (i.e., philosophical naturalism), but he steadfastly maintained that one cannot choose them both.

Although there are individual scientists who espouse philosophical naturalism, science in and of itself makes use of methodological naturalism, not philosophical naturalism (Scott 2009). The difference between philosophical and methodological naturalism is important for understanding the nature of science. As Bailey (2017) stated,

\section{Scientists acknowledge that methodological natu- ralism underlies their research, but point out that they have little choice in the matter. Scientists must assume, when they perform an experiment or make some measurements, that no supernatural entity is disturbing the experimental setup while they per- form the experiment, for otherwise no repeatable empirical study could rationally be performed. After all, making controlled experiments, where the "vari- ables" are fixed one by one, is a key foundation stone of the scientific method. Yet by definition, a scien- tist cannot vary, rule out or "control" in any way the actions of an omnipotent Being who exists beyond the realm of the natural universe and acts beyond its natural laws.}

In other words, although science makes use of methodological naturalism in the conduct of scientific study, science cannot free us from theological questions (Gould 1999, 2003; Nelson 1986). This is an important recognition because it has critical implications for how I began to revise my approach to teaching evolution, especially for non-majors.

\section{Teaching evolution to facilitate understanding the nature of science}

My initial revised instructional framework incorporated several NOS principles (e.g., science is necessarily uncertain, testable, verifiable) throughout my evolution unit of study. My primary intent in designing this unit was to introduce and reinforce how evolution was consistent with NOS principles. A secondary intent, through understanding NOS principles, was to develop a set of claims that were developmentally appropriate for non-majors and science teacher candidates.

The three most effective claims, noted repeatedly in my course evaluations from over a decade of instruction using my revised pedagogy were that: (a) science theories were powerful tools (not facts or beliefs), (b) theories, when presented as new tools, did not necessitate giving back another tool (e.g., theological explanations or aesthetic preferences), and (c) methodological naturalism requires us to put 'blinders' on in order to do the work of science (see below). Considering the first claim, when students asked me if I believe in evolution, I responded playfully, "Do you believe in screwdrivers?" I would then relate to them that I found their use of the word 'belief' associated with a scientific theory as odd as might they in associating 'belief' with a screwdriver. After some additional discussion about theory being as much a useful tool to a scientist as was a screwdriver to a builder when applied to accomplish a specific task, students begin to recognize theories, like evolution, are useful tools in very specific contexts.

I further asked students, as a second claim, to apply theories as the tools of science-used to explain, predict, and solve scientific problems and puzzles. Thinking of theories as tools implied identifying when a theory was the most appropriate tool to apply to a question/problem and knowing how to make use of it to do so. But it is here that I also interject that theories, even if powerful in specific contexts, are but one tool. Other tools, although not necessarily scientific ones, can be equally or more appropriate given a different context-e.g., 'What is your favorite genre of music?' or 'Do humans possess a soul?'-for which an aesthetic or theological tool respectively might be more appropriate to use. I would subsequently point out that in considering evolutionary theory specifically as a tool appropriate to use in a scientific context, I was not asking them to give up other tools they already found to be useful in non-scientific circumstances. This approach is consistent with a thesis introduced by Nelson (1986) in his seminal chapter, Creation, Evolution, or Both? A Multiple Model Approach. 
Finally, I developed as a third claim, that in order to perform scientific work scientists must wear blinders to ways of knowing/explaining that are external to the practice of science. The use of 'blinders' as a metaphor substituted for methodological naturalism. But once the science is done for the day, every scientist has the personal option to remove the blinders and consider other relevant explanations as potential complements to the conclusions reached while engaged in the practice of science. I also emphasize, however, that scientists reject explanations that contradict the scientific evidence-a rival explanation may well be useful in non-scientific contexts, but it is at best 'less' scientific because it fails to be consistent with NOS principles. Once students became accustomed to this perspective or view of science, their resistance to considering a topic like evolution is greatly diminished because they were freed from thinking in a dualistic manner (Perry 1970); in other words, they can keep both tools in their kits. I described this reconciliation of science with other ways of knowing as giving students a place to stand (Scharmann 1990) along a less to more scientific continuum. This place to stand encourages students to reject views that promote an either/or, on/off, theistic/atheistic set of false dichotomies.

These three claims, in summary, promote a classroom environment greatly more receptive to learning about scientific theories, especially evolution (Nelson 1986; Scharmann 1990; Scharmann and Harris 1992). The use of these claims, however, did not appreciably increase student acceptance of evolutionary theory (Scharmann 1994; Woods and Scharmann 2001).

\section{Teaching nature of science as antecedent to evolution instruction}

New insights emerged concerning NOS instruction (McComas 1996; McComas et al. 1998; Abd-El-Khalick and Lederman 2000; Lederman et al. 2002) that caused me to realize that I shouldn't be using evolution as a vehicle to introduce NOS principles. Instead, NOS principles needed to be introduced and well understood before evolution is taught. This recognition became more refined through collaboration with Mike U. Smith, as we delineated the need for future science teachers to become far more literate with respect to NOS in order to facilitate an understanding of these principles among their future students (Smith and Scharmann 1999; Scharmann and Smith 2001). Based on these position papers, we conducted an action research study over a 5 -year period (2002-2006) to test the efficacy of an instructional strategy in which NOS was modeled as an explicit, reflective pedagogy for pre-service science teachers (Scharmann et al. 2005; Smith and Scharmann 2008). Decisions made during the early years of the study, to refine the NOS unit of instruction, are explicated in Scharmann et al. (2005). The aggregated revisions were then integrated into our final NOS instructional unit and retested (Smith and Scharmann 2008).

Data collected in the retest study involved 15 pre-service science teachers and consisted of extensive reflective essays, class discussion summaries, and lesson plans. Learning activities required pre-service teachers to develop criteria that could be used to assess the status of a scientific claim. In one activity, for example, I give students a set of eight statements and ask them to place them along a continuum from least to most scientific. Once accomplished, I pair (or group) students and ask them to share their placements with one another. Where there is disagreement, I request them to arrive at a consensus and eventually make their decision public by display to the class. This activity not only provides a NOS representation of how research groups come to consensus and then defend their position in a public forum, it also provokes them in collaboration to seek a set of criteria by which to judge the placement of the statements (more detail and several other examples can be found in Scharmann et al. (2005). In addition, readings, instructor guidance during class discussions, and electronic mail exchanges directed student thinking toward consensus-informed views of NOS. Multiple opportunities for individual reflections were provided through the use of personal journals in which pre-service teachers proposed justifications for judgments of intelligibility, plausibility, and fruitfulness concerning science-related claims (e.g., claims about evolution, intelligent design, global warming, and genetically-modified foods). Finally, pre-service teachers were asked to create lesson plans that explicitly applied NOS concepts to judgments about issues relevant to both in-school and out-of-school settings.

More recently, a study involving thirty-one community college science non-majors was undertaken by Scharmann and Butler (2015) to replicate the successful NOS-rich instructional environment designed by Butler (2008). Unlike Butler (2008), however, and to correct a shortcoming of his previous study, overt and continuous attention was given to reassure students that they were free to express their honest, personal opinions about the science being taught. Another important difference was a conscious decision to decouple student reflection opportunities from the traditional multiple-choice course assessments that were administered every other week to assess knowledge of biology content (e.g., ecology, evolution, homeostasis, genetics, organisms, physiology). Instead, for the explicit treatment of NOS principles, students were asked to keep a journal, consistent with recommendations offered by Smith and Scharmann (2008), in which they recorded their thoughts about the course 
without fear of getting wrong answers that might lower their overall grades. In their journals, students were encouraged to respond to three focus questions:

- What aspects of the nature of science did you observe in the lessons/activities this week?

- What influence did the recent class activity and discussion have on your understanding of evolution?

- Has your view of evolution changed? Explain your response and provide support or examples of what influenced the change.

Students were required to provide appropriate evidence to use as justification for any claims made in their journal entries. Students also received frequent reassurance, as they studied topics such as evolution, the environment, genetically modified organisms, etc., that it was perfectly valid, in making their journal entries, to accept or reject any scientific claim as long as the decision was based on sound argument and evidence. Instructor feedback targeted a NOS-focused clarification of specific points made in student journals (e.g., evidence considered, inferences based on observations, implied testability and potential for replication of results) by asking students to use observations directly from the class activities, especially in cases where students rejected a specific scientific claim. This use of journaling with non-judgmental feedback provided students a safe outlet to reflect on how they perceived what they were experiencing in class and how they were responding to it.

For research purposes, the instructor analyzed student journal entries from weeks $1,5,9$, and 13 to provide periodic snapshots over the duration of the semester-long course. Their journal entries were globally rated then as "Informed," "Somewhat Informed," or "Not Informed" [note: see Scharmann and Butler (2015) for a discussion of reliability determination]. A comparison of early and late journal entries resulted in a marked increase in NOS understanding (Week 1, 3\% "informed" responses; Week 13, 61\% "informed" responses).

Adding the use of journaling as an assessment tool provided valuable insights above and beyond the factual understanding assessed by traditional summative evaluations. For example, with respect to acceptance of evolution, twenty-seven students rejected evolution (based on their Week 1 entries) and by Week 13, twenty-three of thirty-one students (nearly 75\%) made journal entries (at some point) that specifically remarked on change in their personal acceptance of evolution as a scientific claim. The import of this change is that it is possible to assist students beyond merely understanding evolutionary concepts toward a reconciliation of evolution with their personal religious views. Secondly, and equally important, is that this change can be fostered in the brief span of a single semester course in biology, consistent with the results recently reported by Metzger et al. (2018). This finding is in sharp contrast to those results reported by Butler (2008), who found little acceptance of evolution despite the use of a NOS-rich instructional environment, and Winslow (2008), who found that a reconciliation with religious values can be facilitated, but only after much longer time periods (as many as 4 years of college).

Another critical question addressed in this study was whether or not content understanding was sacrificed due to instructional time given to NOS topics. Students in this study performed equally well on the traditional tests and quizzes compared to prior students (i.e., the instructor noted that the grade distribution for the students in this study was similar to that of sections of the course taught in previous years). Although the number of students in this course was relatively small, the results demonstrate the efficacy of explicit and reflective instruction in which students are free to reflect on their personal responses to the instruction and on feedback to those responses that is individualized, private, and non-judgmental. This work, along with our previous studies, has led to a set of valuable insights about NOS in relation to evolution instruction, which we discuss below.

\section{Insights for teaching NOS and evolution Insight 1-teach explicit NOS principles first}

Early introduction of NOS principles establishes the parameters by which the practice of science is conducted. Over three decades of my work with nature of science in relation to the teaching of evolution, my colleagues and I have integrated NOS in various approaches to instruction (Scharmann 2016). These approaches included the use of NOS: (a) as a culmination (i.e., synthesis) learning (or capstone) experience for non-major biology students (Scharmann 1990); (b) as a parallel focus along with evolution in a non-majors biology course (Scharmann 1994); and (c) as the initial unit of study in both nonmajors biology and pre-service science teaching methods courses (Scharmann et al. 2005; Scharmann and Butler 2015). In the first approach, NOS is explicitly introduced, albeit too late to be a meaningful tool for understanding evolution because reflection opportunities for students are completely missing. In other words, NOS is introduced too late to achieve the intended learning outcome. In the second approach, NOS instruction is both explicit and reflective, but efficacy is hampered by lack of consideration of and planning for possible resistance to evolution while students are concurrently navigating learning NOS principles (Scharmann 2005; Butler 2008). Finally, in the third approach, NOS instruction is explicit, reflective, and presented prior to the introduction of evolution 
so that negative attitudes toward evolution per se do not interfere with NOS learning. NOS principles are constantly referenced in subsequent evolution instruction and are a focus for the remainder of the course.

The efficacy of this third design derives from the fact that NOS is introduced early enough to encourage multiple opportunities for reflection and establish a lens through which students can interpret various science claims, including those of evolution theory and many other topics (e.g., climate change) that students may initially view negatively or as controversial. This third design also made extensive use of a more to less scientific continuum, suggested by Kitcher (1985), in which criteria were developed and applied to determine the placement of fields of study along this continuum (Scharmann et al. 2005). To gain additional practice on how to apply criteria in making consensus decisions, I follow up the eight statements activity that introduced the use of the more to less scientific continuum (see previous section above) with a series of progressively nuanced pairings of fields of study and ask students to come to consensus on where to place them in relation to one another along the continuum. The initial example pairings (e.g., drama with physics, music with chemistry, biology with religion) become more difficult (e.g., genetics with computer science, sociology with political science, engineering with astrophysics) leading to rich discussions of pure versus applied sciences and blurred lines even between the major science disciplines-biochemistry, biophysics, geophysics, etc. Additional detail is provided in Smith and Scharmann (2008).

Ultimately, using this continuum approach allows students to consider a field of study making scientific claims (e.g., Intelligent Design, Astrology) against a set of criteria and place it along the continuum without forcing them to completely dismiss it as non-scientific. Even those students most initially resistant to evolution eventually (some with reluctance) recognize that Intelligent Design (ID) may be appealing as an explanation on personal, aesthetic, or theological grounds, but they concede (based on the application of NOS principles) that ID is far less scientific compared to evolution (Smith and Scharmann 2008).

The necessity of integrating NOS with content throughout a course of study continues to be recognized (Lederman and Lederman 2014; Abd-El-Khalick 2013; Lederman 2004; Khishfe and Abd-El-Khalick 2002). Integration of NOS is likely even more critical for college students whose major is other than science (Borgerding et al. 2017; Price and Rogers 2016; Scharmann and Butler 2015; Hermann 2008) and especially relevant for science teaching candidates (Borgerding and Dagistan 2018; Friedrichsen et al. 2016; Glaze et al. 2015; Pobiner 2016).
Glaze et al. (2015) specifically noted among pre-service science teachers that a deep understanding of NOS principles is a statistically significant positive factor in influencing a personal acceptance of evolution.

\section{Insight 2-evolution instruction must be integrated as a theme throughout an introductory biology course}

A crucial connection to emphasize between evolutionary theory and NOS principles is that in order to grasp the power of a scientific theory to explain, predict, and solve scientific problems, one must also understand the limits of that theory, e.g., that evidence in support is required, what kinds of questions can and cannot be addressed, what questions and observations remain unexplained, and the strength of the evidentiary support for and against the theory. Students accustomed to the use of NOS principles as a lens for understanding science content become more capable of recognizing that evolutionary theory does not preclude other explanations from being relevant; however, students also become able to see that these other explanations are far less scientific (Scharmann et al. 2005; Smith and Scharmann 2008).

In addition to interweaving evolutionary concepts with NOS principles, it is equally important to illustrate the practical significance of evolutionary concepts. In other words, there are human elements in science that illustrate the relevance of evolutionary biology for making individual and societal decisions. For example, I want students to understand why acquired traits such as musical ability are not inherited and how species (not individuals) adapt to their environment over time. Likewise, I want students to recognize how the Centers for Disease Control and Prevention apply the principle of common ancestry to the design and production of vaccines. Finally, integrating evolutionary concepts with NOS in instruction, my colleagues and I have found that students who express strong religious beliefs become more willing and able to reconcile their science learning (specifically evolution) with their religious beliefs (Smith and Scharmann 2008; Winslow et al. 2011; Southerland and Scharmann 2013; Scharmann and Butler 2015).

\section{Insight 3-active learning promotes critical thinking and enhances evolution understanding}

The promotion of active learning has a long history in the science education community (Posner et al. 1982; Carey et al. 1989; Hewson et al. 1998). Even though active learning is known to be associated with gains in critical thinking in general, Nelson (2007) has noted a deep-seated reluctance in the higher education science community to adopt instructional methods that actively engage students despite evidence that active learning improves student performance (Carmichael 2009), reduces attrition 
(Dinan 2004; Comeford 2016), enhances long-term retention and critical thinking (McInerney and Fink 2003), and provides a particularly interesting context for learning science in general (Borgerding and Dagistan 2018) and evolution most specifically (Scharmann 2005). To make matters worse, university instructors are even more hesitant to employ active learning when teaching about evolution for fear of losing control of the classroom discussion (Barnes et al. 2017; Nelson 2000).

Our studies to date on active learning with college nonmajors (Scharmann et al. 2005; Scharmann and Butler 2015) and pre-service science teachers (Scharmann 2005; Smith and Scharmann 2008) have clearly demonstrated that a strong foundation in NOS acquired through active learning prepares students to deal with their perceptions of science controversies. Earlier in the descriptions of the eight statements activity and follow-up example delineated in Insight 1, I described extensive use of studentto-student interactions in pairs, groups, and/or teams, that is immediately debriefed using teacher-to-student interactions (e.g., question and answer or instructorfacilitated whole class discussion). Another example to illustrate the capacity of more active forms of learning to engage students in critical thinking is when I ask future science teachers (in a peer-discussion format) to role-play as members of a community faced with the decision to teach evolution in their school district. The introductory scenario has changed with time-early career I provided teacher candidates with the 1987 Edwards vs. Aguillard decision (National Center for Science Education 2018a), middle career it was the 1999 Kansas State Board of Education Decision to allow every individual school district to decide whether to include evolution as a part of their curriculum, and later career I used the Kitzmiller vs. Dover decision (National Center for Science Education 2018b) - but in each case the focal questions being discussed request pre-service teachers to consider a presentation of the relevant facts and a follow-up request that each team come to consensus on recommending (or not) the teaching of evolution in their fictitious communities. I then ask the teams to present their recommendations, highlighting their major reasons for and against teaching evolution [note: I learned through the earliest example how important it was to know my students well enough to purposely form discussion groups based on my observations and interactions with them and to not leave the group to form either randomly or by self-selection. Additional insight into this recommendation can be found in Scharmann and Hampton (1995)].

Through team-based, problem-based, and cooperative learning, students influence (persuade) one another's positions with less threat than is the case when an individual student perceives that they may be on the opposing side of their instructor's position. In addition, by having peers discuss their observations from inquiry and laboratory activities before addressing issues they perceive as controversial, instructors can monitor students' discussions and better prepare them to consider discrepancies that may arise in subsequent whole-class discussions (Winslow et al. 2011; Sibley and Ostafichuk 2014; Scharmann and Butler 2015).

\section{Insight 4-use of non-threatening assessments promotes examination of personal views about controversial subjects}

In the first three insights presented above my colleagues and I have argued that the introduction of NOS principles before learning about science content, the frequent use of NOS principles as a lens through which to interpret evolutionary concepts can be understood with a minimum of conflict with prior beliefs, and students' engagement promote deeper individual reflection concerning the scientific concepts and principles to be learned. Our previous studies, in concert with other researchers, also demonstrate the value of non-threatening assessment practices to deal with the affective (or emotional) concerns of our students (Nelson 2007; Winslow 2008; Scharmann and Butler 2015).

Nelson (2007) provided a strong rationale for instructional practices that takes students' prior beliefs into account. To this point, Winslow (2008) added that without making comparisons between personal and scientifically more accurate conceptions, a reconciliation of students' religious beliefs with scientific concepts is unlikely to occur. In other words, in the case of evolution instruction at least, a conceptual change instructional model alone can be insufficient for achieving reconciliation of one's personal beliefs with an understanding of evolutionary theory.

The use of journals as a non-threatening assessment tool permits students to engage in introspective, honest, reflective expressions of progressive changes in personal views and understandings and to develop skill at using evidence to support inferences and conclusions. The success of the use of this assessment approach is highly dependent on an instructor's skill and willingness to provide consistent, unbiased, and non-threatening feedback to students. Working with high school students, for example, Janelle Mead and I asked high school biology students to adopt one of four major characters in the film Inherit the Wind and keep a journal reflecting their adopted character. The film was watched in 20-30 min segments. Following each segment, students discussed their insights concerning their character in relation to the study of evolution as it was presented in the film. After 4 days and at the conclusion of the film, 
we asked students to form groups coinciding with the character they adopted (e.g., a Clarence Darrow or William Jennings Bryan group), discuss their insights, come to consensus, and choose one spokesperson to represent their group on the final day of the role play. We continuously reassured students that it was their participation that was most important and not their individual view of evolution. The student engagement, in the content and their positive reactions/insights to the use of journals as a non-threatening assessment, is described in Mead and Scharmann (1994). Likewise, in the 2015 study, as another example to reassure that student participation was without negative consequence, it was often repeated in class, "Remember, we are only concerned with where your evidence leads you. We are not judging you as right or wrong. We want you each to feel comfortable discussing the evidence with one another and with us in an open and mutually respectful manner" (Scharmann and Butler 2015).

Journaling, therefore, in both of these examples, promotes reflection on the:

- Special nature of scientific knowledge-specifically reinforcing that science is necessarily uncertain, testable, replicable, and self-correcting,

- Tools and products of science-specifically that evidence is required and that science typically shares various empirical methods-observations, inference, inference, deduction,

- The human elements of science-specifically that science aims for objectivity but recognizes that subjectivity cannot be eliminated and that science is therefore impacted by social and cultural influences such as those that students bring with them to class, and

- Compatibility of the science being learned with prior religious beliefs-by providing multiple opportunities for students to try out changes in personal understanding of science concepts like evolution and discover ways that reasonable people can both accept evolution and hold certain religious beliefs, thereby giving students a new place to stand.

\section{Summary}

In this paper I have asserted four insights concerning the influence and efficacy of teaching NOS prior to the introduction of evolution within college courses for science non-majors and science teacher candidates. These insights are:

1. It is important in teaching science non-majors to establish NOS principles first, through focused learn- ing, prior to the introduction of other science concepts;

2. Evolution instruction should be integrated as a theme throughout an introductory biology course after NOS instruction and explicitly linked to NOS principles;

3. Students should be engaged in active learning that enhances opportunities for critical thinking, peer-topeer interactions, and student-to-instructor interactions as they study NOS and evolutionary concepts; and

4. Assessments concerning NOS, and the learning of topics (such as evolution) perceived by students as controversial, should be as non-threatening as possible to permit students to compare initial beliefs about science with evidence obtained in active learning experiences.

Together, these insights establish a pedagogy that I (and my colleagues) have found to be efficacious for supporting novice students as they engage in the study of evolutionary science.

Adopting efficacious pedagogies to replace outmoded ones in postsecondary education is an intentional choice. Although these methods have been slow to be considered at the post-secondary level (Freeman et al. 2014; Nelson 2010), it is essential that we move in this direction. If we do not, we will continue to fail to meet the needs of science non-majors (Short and Hawley 2015; AAAS 2011; Nehm et al. 2009), who represent the majority of students enrolled in post-secondary introductory biology courses. We will also fail to adequately prepare science teacher candidates in how best to teach evolution to their future students (Borgerding and Dagistan 2018; Glaze et al. 2015; Hermann 2013; Smith and Scharmann 2008; Scharmann et al. 2005; Rutledge and Warden 2000). To continue to serve these student populations poorly puts at risk the political decision-making (i.e., by informed voters) needed within a citizenry to make individual health and societal decisions based on accurate scientific reasoning.

\footnotetext{
Authors' contributions

This paper was written by LCS. The author read and approved the final manuscript.
}

\section{Acknowledgements}

Mike U. Smith provided invaluable reviews of multiple iterations of this paper. Mike and I conversed about the voicing of the paper potentially changing from I to we with respect to the first half (my personal early journey in teaching evolution) versus second half of the paper (which details our work together). It was a consensus decision that the paper made a much stronger statement from a first-person perspective. However, because of Mike's collaboration, the middle to latter part of my career has been far richer and more productive. Our collaboration is pervasive in and reflected by the insights reported here. 


\section{Competing interests}

The author declares no competing interests.

\section{Availability of data and materials}

Not applicable.

\section{Funding}

Not applicable.

\section{Publisher's Note}

Springer Nature remains neutral with regard to jurisdictional claims in published maps and institutional affiliations.

Received: 21 August 2018 Accepted: 3 October 2018

Published online: 06 October 2018

\section{References}

AAAS. Vision and change in undergraduate biology education: a call to action. Washington, DC: American Association for the Advancement of Science: 2011.

Abd-El-Khalick F. Teaching with and about nature of science, and science teacher knowledge domains. Sci Educ. 2013;22:2087-107.

Abd-El-Khalick F, Lederman N. The influence of history of science courses on students' views of the nature of science. J Res Sci Teach. 2000:37:1057-95.

Bailey DH. Is 'methodological naturalism' presumed in modern science? 2017. http://www.sciencemeetsreligion.org/philosophy/methodological-natur alism.php. Accessed 9 Aug 2018.

Barnes ME, Elser J, Brownell SE. Impact of a short evolution module on students' perceived conflict between religion and evolution. Am Biol Teach. 2017;79:104-11

Borgerding LA, Dagistan M. Pre-service science teachers' concerns and approaches for teaching socioscientific and controversial issues. J Sci Teach Educ. 2018;29:283-306

Borgerding LA, Deniz H, Anderson ES. Evolution acceptance and epistemological beliefs of college biology students. J Res Sci Teach. 2017;54:493-519.

Butler W. Does the nature of science influence college students' learning of biological evolution? (Doctoral dissertation). Electronic Theses, Treatises and Dissertations (Paper 22415). 2008. http://fsu.digital.flvc.org/islandora/ object/fsu\%3A180616. Accessed 4 Oct 2018

Carey S, Evans R, Honda M, Jay M, Unger C. An experiment is when you try it and see if it works: a study of grade 7 students' understanding of the construction of scientific knowledge. Int J Sci Educ. 1989:11:514-29.

Carmichael J. Team-based learning enhances performance in introductory biology. J Coll Sci Teach. 2009:38(4):54-61.

Comeford L. Team-based learning reduces attrition in a first-semester general chemistry course. J Coll Sci Teach. 2016;46(2):42-6.

Dinan FJ. An alternative to lecturing in the sciences. In: Michaelson LK, Knight $A B$, Fink $L D$, editors. Team-based learning: a transformative use of small groups in college teaching. Sterling: Stylus Publishing; 2004. p. 97-104.

Freeman S, Eddy SL, McDonough M, Smith MK, Okoroafor N, Jordt H, Wenderoth MP. Active learning increases student performance in science, engineering, and mathematics. Proc Natl Acad Sci USA 2014:111(23):8410-5.

Friedrichsen PJ, Linke N, Barnett E. Biology teachers' professional development needs for teaching evolution. Sci Educ. 2016;25:51-61.

Glaze AL, Goldston MJ, Dantzler J. Evolution in the southeastern USA: factors influencing acceptance and rejection in pre-service science teachers. Int J Sci Math Educ. 2015;13:1189-209.

Gould SJ. Rocks of ages: science and religion in the fullness of life. New York: The Ballantine Publishing Group; 1999.

Gould SJ. The hedgehog, the fox, and the magister's pox. New York: Harmony Books; 2003.

Hermann R. Evolution as a controversial issue: a review of instructional approaches. Sci Educ. 2008;17:1011-32.

Hermann R. High school teachers'views on teaching evolution: implications for science teacher educators. J Sci Teach Educ. 2013:24:597-616.
Hewson PW, Beeth ME, Thorley NR. Teaching for conceptual change. In: Tobin KG, Fraser BJ, editors. International Handbook of Science Education. Dordrecht: Kluwer Academic Publishers; 1998. p. 199-218.

Johnson PE. Darwin on trial. 2nd ed. Downer's Grove: Intervarsity Press; 1993. Khishfe R, Abd-El-Khalick F. Influence of explicit and reflective versus implicit inquiry-oriented instruction on sixth graders' views of nature of science. J Res Sci Teach. 2002;39:551-78.

Kitcher P. Good science, bad science, dreadful science, and pseudoscience. J Coll Sci Teach. 1985:14:168-73.

Kuhn TS. The structure of scientific revolutions. 4th ed. Chicago: The University of Chicago Press; 2012.

Lederman NG. Syntax of nature of science within inquiry and science instruction. In: Flick LB, Lederman NG, editors. Scientific inquiry and nature of science: implications for teaching, learning, and teacher education. Dordrecht: Kluwer Academic Publishers; 2004. p. 301-17.

Lederman NG, Lederman JS. Research on teaching and learning of nature of science. In: Lederman NG, Abell SK, editors. Handbook of research on science education, vol. II. New York: Routledge; 2014. p. 600-20.

Lederman NG, Abd-El-Khalick F, Bell RL, Schwartz RS. Views of nature of science questionnaire: toward valid and meaningful assessment of learners' conceptions of nature of science. J Res Sci Teach. 2002;39:497-521.

McComas WF. Ten myths of science: reexamining what we think we know about the nature of science. Sch Sci Math. 1996;96:10-5.

McComas WF, Clough MP, Almazroa H. The role and character of the nature of science in science education. Sci Educ. 1998:7:511-32.

Mclnerney M, Fink LD. Team-based learning enhances long-term retention and critical thinking in an undergraduate microbial physiology course. J Microbiol Biol Educ. 2003;4:3-12.

Mead J, Scharmann LC. Enhancing critical thinking through structured academic controversy. Am Biol Teach. 1994;56:416-9.

Metzger KJ, Montplaisir D, Haines D, Nickodem K. Investigating undergraduate health sciences students' acceptance of evolution using MATE and GAENE. Evolution. 2018. https://doi.org/10.1186/s12052-018-0084-8.

National Center for Science Education. Edwards v. Aguillard. 2018a. https:// ncse.com/library-resource/edwards-v-aguillard. Accessed 28 Sept 2018.

National Center for Science Education. Kitzmiller v. Dover: Intelligent design on trial. 2018b. https://ncse.com/library-resource/kitzmiller-v-dover-intel ligent-design-trial. Accessed 28 Sept 2018.

Nehm RH, Kim S, Sheppard K. Academic preparation in biology and advocacy for teaching evolution: biology versus non-biology teachers. Sci Educ. 2009;93:1122-46.

Nelson CE. Creation, evolution, or both? A multiple model approach. In: Hanson Robert E, editor. Science and creation. New York: Macmillan; 1986. p. 128-59.

Nelson CE. Effective strategies for teaching evolution and other controversial topics. In: Skehan WJ, Nelson CE, editors. The creation controversy and the science classroom. Arlington: NSTA Press; 2000. p. 19-50.

Nelson CE. Teaching evolution effectively: a central dilemma and alternative strategies. McGill J Educ. 2007:42:265-84.

Nelson CE. Dysfunctional illusions of rigor: lessons from the scholarship of teaching and learning. In: Nilson LB, Miller JE, editors. To improve the academy: resources for faculty, instructional, and organizational development. San Francisco: Jossey-Bass; 2010. p. 177-92.

Perry WG. Forms of intellectual and ethical development in the college years: a scheme. New York: Holt, Rinehart, and Winston; 1970.

Pobiner B. Accepting, understanding, teaching, and learning (human) evolution: obstacles and opportunities. Am J Phys Anthropol. 2016;159:232-74.

Posner GJ, Strike KA, Hewson PW, Gertzog WA. Accommodation of a scientific conception: toward a theory of conceptual change. Sci Educ. 1982;66:211-27.

Price $M$, Rogers $M$. Teaching nature of science through scientific models: the geocentric vs. heliocentric cosmology. J Coll Sci Teach. 2016:46(2):58-62.

Rutledge ML, Warden MA. Evolutionary theory, the nature of science and high school biology teachers: critical relationships. Am Biol Teach. 2000;62:23-31.

Scharmann LC. Enhancing an understanding of the premises of evolutionary theory: the influence of a diversified instructional strategy. Sch Sci Math 1990;90:91-100.

Scharmann LC. Teaching evolution: designing successful instruction. J Sci Teach Educ. 1994;5:122-9. 
Scharmann LC. A proactive strategy for teaching evolution. Am Biol Teach. 2005;67:12-6.

Scharmann LC, Butler W. The use of journaling to assess student learning and acceptance of evolutionary science. J Coll Sci Teach. 2015;45:11-6.

Scharmann LC, Hampton CMO. Cooperative learning and preservice elementary science self-efficacy. J Sci Teach Educ. 1995;6:125-33.

Scharmann LC, Harris WM. Teaching evolution: understanding and applying the nature of science. J Res Sci Teach. 1992;29:375-88.

Scharmann LC. A retrospective on student learning and acceptance of evolutionary science. 2016. http://digitalcommons.unl.edu/dberspeakers/93. Accessed 13 Aug 2018.

Scharmann LC, Smith MU. Further thoughts on defining versus describing the nature of science: a response to Niaz. Sci Educ. 2001;85:691-3.

Scharmann LC, Smith MU, James MC, Jensen M. Explicit reflective nature of science instruction: evolution, intelligent design, and umbrellaology. J Sci Teach Educ. 2005;16:27-41.

Scott EC. Evolution vs. creationism: an introduction. 2nd ed. Berkely: University of California Press; 2009

Shamos MH. The myth of scientific literacy. New Brunswick: Rutgers University Press; 1995

Short SD, Hawley PH. The effects of evolution education: examining attitudes toward and knowledge of evolution in college courses. Evol Psychol. 2015;13:67-88
Sibley J, Ostafichuk P. Getting started with team-based learning. Sterling: Stylus Publishing; 2014

Smith MU, Scharmann LC. Defining versus describing the nature of science: a pragmatic analysis for classroom teachers and science educators. Sci Educ. 1999;83:493-509.

Smith MU, Scharmann LC. A multi-year program developing an explicit reflective pedagogy for teaching pre-service teachers the nature of science by ostention. Sci Educ. 2008;17:219-48.

Southerland SA, Scharmann LC. Acknowledging the religious beliefs students bring into the science classroom: using the bounded nature of science. Theory Pract. 2013;52:59-65.

Winslow MW. Evolution and personal religious belief: christian biology-related majors' search for reconciliation at a Christian university (Doctoral dissertation). 2008. http://krex.k-state.edu/dspace/handle/2097/710. Accessed 13 Aug 2018.

Winslow MW, Staver JR, Scharmann LC. Evolution and personal religious belief: christian university biology-related majors' search for reconciliation. J Res Sci Teach. 2011;48:1026-49.

Woods CS, Scharmann LC. High school students' perceptions of evolutionary theory. Elec J Sci Educ. 2001; 6(2). http://ejse.southwestern.edu/article/ view/7676. Accessed 16 Aug 2018.
Ready to submit your research? Choose BMC and benefit from:

- fast, convenient online submission

- thorough peer review by experienced researchers in your field

- rapid publication on acceptance

- support for research data, including large and complex data types

- gold Open Access which fosters wider collaboration and increased citations

- maximum visibility for your research: over $100 \mathrm{M}$ website views per year

At BMC, research is always in progress.

Learn more biomedcentral.com/submissions 